\title{
THE "MONOLINGUAL HABITUS" AS THE COMMON FEATURE IN TEACHING IN THE LANGUAGE OF THE MAJORITY IN DIFFERENT COUNTRIES
}

Ingrid Gogolin

This article describes a fixed pattern of assumptions about language learning implicit in the idea of a national language, and explores their role in failure in the multilingual, multicultural classroom. These examples are drawn from Europe, but they raise important issues for multilingual countries like South Africa with a dominant language of education.

In hierdie artikel word 'n gevestigde patroon van aannames ondersoek oor die aanleer van 'n taal soos dit duidelik na vore kom in die opvatting oor ' $n$ nasionale taal; verder word die rol wat dit by mislukking in die veeltalige, multikulturele klaskamer speel, ontleed. Hierdie voorbeelde word aan Europa ontleen, maar dit bring belangrike vraagstukke na vore in veeltalige lande soos Suid-Afrika waar ' $n$ dominante taal van onderrig voorkom.

\section{INTRODUCTION}

This article is divided into three parts. First, I recount a sequence from a routine lesson in a primary school in Hamburg, Germany to demonstrate some functional aspects of what I have named "monolingual habitus". In the second part I explore the term "monolingual habitus". The third part is a reflection on the concept of "monolingual habitus" as a "tertium comparationis" (or area of common ground) as we compare mother tongue teaching (teaching in the language of the national majority in multilingual classrooms) internationally. This discussion may suggest ways in which the concept of "monolingual habitus" could be useful in South African research.

\section{EXCERPT FROM A ROUTINE LESSON IN A HAMBURG PRIMARY SCHOOL ILLUSTRATING THE "MONOLINGUAL HABITUS"}

The situation I am about to describe is drawn from a recording of a week's teaching in the third grade of a Hamburg primary school. The children are 9 years old. The national, ethnic and linguistic background of the pupils makes this school an almost perfect reflection of the average inner-city Hamburg primary school. Immigrant children constitute approximately $50 \%$ of the school's population. In a broader sense, this school may be taken as typical of schools in Western European nation states, which all face an increasing number of immigrants and thus a growing ethnic, cultural and linguistic heterogeneity in their societies. 
The lesson is a German one. We shall focus on the moment at which the planned lesson goes wrong.

The teacher - Frau Schiller - begins the language lesson by initiating revision of an exercise. In order to make her intention clear to the children, she writes on the blackboard: Opposites. She explains that she will now write a word on the board and whoever knows the opposite should answer. She writes: rough; she paraphrases: shaggy (using an informal, regional word rubbelig); the children propose examples of opposites: fine, unrough, soft, hard, grey (here the answering child must have thought that what was wanted was a rhyming word, so offers grau which rhymes with rauh.... Although some of these examples are plausible, all are refused. Frau Schiller thinks aloud: "What, then, is rough in the classroom...?" She rubs her hand over Jimmi's pullover ("This is rough"), and then over the desktop ("and this here is...?"). Maryn calls out first: "smooth"; the answer is accepted; he is praised. The lesson continues in this pattern. Frau Schiller writes hungry on the board, the children present examples of "opposites", Annalisa says "fuil" and gets the praise. Frau Schiller writes hard on the board; someone says "unhard"; Annegret improves on this: "soft" - and has found the correct answer. Frau Schiller writes the German word arm on the board. Ferhat offers the answer: "shoulder". Someone suggests "elbow". Quietly, someone says, "foot". Enrico comments on the writing on the board: "You wrote arm wrong - the arm. " Frau Schiller acknowledges that there is a problem here: "First we have to ask what kind of words these are." Someone offers: "Do-words" (the expression is widely used for "verbs" in primary school teaching). This is not the right answer. Then someone calls out: "Like-words" (expression used for "adjectives"). Frau Schiller confirms the answer, saying: "Like-words tell us what something or someone is like, and so: When someone is not poor ( $\mathrm{arm})$ he is. . . ?" - "Rich" - Conni says the word. Someone comments that it is not so in reality - not everyone who is not poor is rich. The exercise is continued.

A word of explanation is necessary before we attempt an interpretation of this incident. There is no difference in sound between the German words arm (English: poor) and Arm (English: arm). However, when written there is a clear difference in meaning, because nouns (der Arm: English: the arm) have an initial capital letter. The orthographic-semantic difference between nouns (written with initial capitals) and other words is widely covered in German grammar and writing exercises in primary schools.

Let us return to the lesson. We seem to be concerned here with a rather banal everyday occurrence: part of a lesson fails because the teacher's view of something is different from that of part of the class. However, there is more to it. For Frau Schiller the content signal that is implicit in the sought after "opposites" is only a means to an end. Her real purpose is for the children to practise a category of German grammar: that is, a word class known as "the adjective". The children take the signal given as the real task. For them, the object of the exercise is achieved in treating "arm" as a noun, and, in fact, on the human body a leg is something like the opposite of an arm.

From the point of view of a person who is interested in the question of mother tongue teaching - understood as teaching in the language of the majority to students from a 
multilingual background in European schools - the children's misinterpretation (or different notion of the task) is not the fundamental reason why the lesson runs aground. From my point of view [I call it the intercultural viewpoint] the constellation of the interaction must be observed very attentively. Only this can take us to the underlying cause of the failure. It enables us to see that the misunderstanding between teacher and children is triggered because the help the teacher offers consists of practically nothing other than an appeal to a common feeling for language. The teacher is not conscious of using this practice. Only when such a common feeling for the language is present, is it possible for a question about "the opposite" to elicit reflexively the answer that the teacher takes for granted: the use of one word only, namely one that belongs to the grammatical category "adjective" as signalled in this case by the lower case spelling.

It is therefore no accident that the problem in the lesson becomes obvious at the moment that Ferhat works on the question. He is a child from an immigrant family, as are $50 \%$ of the children in that class. He is one of those children whose language socialisation happened neither in German nor exclusively in one language, but who is growing up and living in bilingual circumstances. Such children develop a completely different feeling for language from what the teacher assumes (see Gogolin, 1988; Gogolin, 1993). Proof of this has been extensively explored in language learning research. Completely independent of the degree of mastery of the two languages and also independent of the developed concrete shape of either of the affected languages, the language learning disposition of children growing up bilingually is fundamentally different from that of monolingual children, and that is so in practically every imaginable respect.

Seen from an intercultural point of view, this example from an everyday lesson in an average European classroom makes clear: that in offering the well-intentioned help the teacher assumes a mother tongue context where nothing must actually be learned, but rather everything is already known or can be mastered by refining what is already instinctively there. It can be argued that this highlights a fundamental difference between first language and second language learning development: in second language or multicultural settings the teacher cannot assume that a rich store of prior knowledge of this kind already exists.

\section{THE "MONOLINGUAL HABITUS": CONCEPT AND IMPLICATIONS}

If one looks into "mother tongue" teaching from the intercultural point of view that 1 propose, it is often revealed - as in the example shown - that the chances and possibilities of learning are impeded for non-mother tongue learners by the assumptions of the teacher. And not only that: the fact that the didactic mode which is intended to be helpful in fact negates itself, remains mostly unnoticed, because the teaching is widely based on the unspoken assumption that the students are a homogeneous group. To be more precise, the teaching relies on the assumption that the children all grow up within the bounds of the same social class, culture or ethnic group and language. This assumption has persisted despite all the evidence of the differences in living situations and roles in a functionally diversified, complex society. The very different living conditions and life experiences of the children in a de facto multicultural and multilingual society are thereby made invisible for a school philosophically dependent on the fundamental myth of homogeneity of language and culture in a national society. 
This phenomenon permeates the structures and forms of most European schools. It is founded on the basic and deep-seated conviction that monolingualism in a society, and particularly in schools, is the one and only normality, forever and always valid: the characteristic of a nation. This leads to what I describe as the monolingual "habitus": the deep-seated habit of assuming monolingualism as the norm in a nation. I would go so far as to suggest that the "monolingual habitus" is an intrinsic characteristic of the classical European nation state, that is to say, of those nation states which were established in the 18th and 19th centuries and to all nations established in that tradition (cf. Heckmann, 1992 and Hobsbawm, 1991 for reflections on the concepts of nation).

The establishment of these nation states was accompanied by the foundation of their public school systems. One of the main motives for the development of education systems was linguistic homogenisation: the establishment of one national language and of a monolingual national society honouring one standard form of a language. This was seen as essential for the ultimate economic success of the nation state idea. Germany is one of the nations with this tradition of monolingualisation of its people in the, 19th century. The "monolingual habitus" is thus an essential constitutive element of the German state school system. It is reflected in educational norms, structural precedents, and the content of teaching. And it governs the language-directed perceptions, attitudes and activities of the teachers (see Gogolin, 1994 for research evidence).

I should add here that there is likely to be a difference between the dominant European concept of nation and the national concepts of many of the so-called young nation states - for example, in the Indian subcontinent, Australasia and southern Africa. Probably these nations do not relate national identity and self-confidence to national monolingualism (cf. for example Clyne, 1991). Nevertheless, I suspect that the "monolingual habitus" will turn out to be a concept which is also relevant to multilingual nation states of a certain type and their school systems. This is, I admit, a question which requires further research. I would argue that a "monolingual habitus" is likely to be at work in multilingual nations as well, due to the fact that there is usually one language of power. This may be a national language, like English in South Africa, but it is not necessarily so. The language which concerns me is the one which guarantees survival and success in the linguistic market(s).

The concept of "'monolingual habitus"' is inspired by Pierre Bourdieu's use of the term "habitus" for a modus which generates dynamic changes in human activity. Bourdieu's theory attempts to describe the dynamic relationships between:

* the structural conditions of an individual existence on the one hand

* the individual's activities as a product of socialisation under these conditions on the other hand

* and, as a third field of influence, the endless and at the same time strictly limited capacity of the individual to act.

Bourdieu describes these relationships as follows. In the individual, through socialisation, a system of permanent dispositions is created, which contains "susceptibility" as one prerequisite for personal development. This system of dispositions and susceptibility creates the preconditions for successful social activity and also the preconditions for the a person's 
not needing to reflect and decide consciously upon his or her normal daily activities. That is to say, a "habitus" is the necessary precondition for a person to act routinely.

Bourdieu emphasises the cyclical interdependence of structure, "habitus" and practice. "habitus", which functions as awareness-matrix, action-matrix and thought-matrix, is acquired under certain social conditions which Bourdieu calls "objective structures". To these belong, for example, the existential requirements which characterise and define a social class. "habitus", therefore, defines and generates the activities of its members, who themselves influence, create and recreate their living-conditions. In this dynamic relationship, "objective structures" are regenerated through history and thus regenerate a "habitus". Bourdieu describes this as follows. He says that the "habitus" functions as "structured structures, which are suitable to function and work as structuring structures" (Bourdieu, 1979: 167f).

As I have already mentioned, the "habitus" makes it possible for its constituents to act routinely. And at the same time it puts them in a position to deal with unexpected, new situations, without reacting to them with paralysis. Implicit in the concept of "habitus" is a tendency toward self-stabilisation - and this holds also for the case where people are forced to act in radically new situations. The socialisation of the individual is not completed until death. Everyone always has new experiences, which are integrated in his or her "habitus". This results in constantly changing forms of a "habitus" which, nevertheless, remains stable as a comprehensive system at a higher level.

The possibility of interpreting job-typical attitudes, activities and products as "professional habitus" is opened by the introduction of the concept of "lifestyle". Bourdieu clarifies this by saying that the working "habitus" incorporates the total activity of an actor and therefore also the group of actors who come from a similar social environment. They are to be seen as products of the activity of identical schemata which carry a systematic character. They are therefore systematically differentiated from the constituent forms of activity of a different lifestyle.

Under this category comes the occupation of teacher. There is a subject-specific "habitus" in this occupation because of training, social status and working environment. The teacher's circumstances can be differentiated clearly from circumstances which are specific to other professions. Therefore one can say that a subject-specific "habitus" for teachers exists (cf. Liebau \& Huber, 1985). This is is also attested by everyday experience. When a group of people meet for the first time, a teacher soon recognises other teachers, just as a lawyer recognises other lawyers or a doctor other doctors.

With these reflections and research findings in mind, I formulated the following hypothesis: the monolingual orientation which can be observed among teachers in German and other European schools is an intrinsic element of their professional "habitus" as members of the nation state school system (for a similar analysis of the Dutch school system see Kroon \& Sturm, 1994). This professional "habitus" means that establishing monolingualism in the official national language is an imperative in a teacher's professional ethos. The "monolingual habitus" has been built and secured through the traditions of the educational system itself. It operates more effectively the less conscious the individual teacher is about its existence (for more detail on the concept of "habitus", see Bourdieu, 1979, 1984, 1985, 1987). 
Isolated observation leaves much unclear, because it reveals so many contradictory features. However, when the monolingual orientation of teachers is recognised as an element of their professional "habitus", it is possible to understand better what happens in the multilingual classrooms of schools of immigrant-countries in Europe. A good example is a case study by Sjaak Kroon of intercultural teaching in the Netherlands. I quote a shortened excerpt from one of his observation protocols. The lesson was in Dutch.

The example shows a teacher who intends to deal with the linguistic diversity in her classroom. The intention is that the class reflects on the question of how words are adopted by one language from another. In the first part of the lesson the class have to think about "exotic" words which have been incorporated into Dutch (like the word "sugar", deriving from India). In the second part, their task is to think about how Dutch words found their way into other languages: words like bâbord, tribord, yacht in French etc. Now, the intention goes awry:

T: So, what does the word "bâbord" mean?

Stud: (confused) I don't know. What? Port. (Dutch: bakboord)

T: Port, good, port, very good. And "tribord" means...?

Stud: Starboard (Dutch: stuurboord).

'T: Starboard. Why do you think that these words were used in French? (Silence) They come from Dutch. Why do you think that it happened? (Quiet; no reaction) Why do you think that words like port and starboard. .. ?

[(... ); no reaction to the teacher's questions; and so to her explanation:]

T: Of course you know that these are the two sides of a ship, don't you? One doesn't talk about left and right, rather of port and starboard.

Again the teacher makes an attempt to return to the answer to the central question:

T: Why do you think that the words are there in other languages?

Stud: ???????? (complete silence)

The children don't understand what the teacher wants from them. So she gives the answer herself.

T: Because Holland is very important in shipping and so many words from here were taken over by others.

Stud: Why is that the case?

Once again, the teacher has to supply the answer. 
T: Why? Because Holland had much to do with shipping.

The students don't follow her argument, so she has to repeat it several times. Then she tries the technique once again with the word "yacht" - and again it doesn't work. Now she reaches for an explanation.

T: That is the same again: "yacht" also has something to do with shipping, and we have done a great deal in this area and that's why we have so many words about it.

Stud: How did they get into the other language?

T: For the same reason. Holland is very well developed in that area, so there are a lot of Dutch words from 'it in other languages. Let's look at "Matjesherring".

The teacher tries again - unsuccessfully - in the same way. She realises, finally, that something has gone wrong. She reacts with recrimination when a student says:

Stud: Miss, I don't follow.

T: Yes, if you would participate normally then it wouldn't be a problem, but if you don't do that then it's rather difficult (for the whole transcript see: Kroon \& Vallen, 1991; see also Kroon, 1986).

The group of participants in the lesson observed by Sjaak Kroon consisted of eight Surinamese, two Turks, three Moroccans, one Portuguese and six Dutch children. The teacher who was observed here was prompted by the best motives with regard to the declared intent of presenting the theme of language diversity to her multilingual class. The problem she encountered was, in my view, the result of her "monolingual habitus". One recognises that in a closer look at the following:

Even at the moment when ethnic and language diversity are obvious to the teacher - in fact it provides the motive for choosing the international theme of the exercise - her behaviour is more strongly determined by "assumed similarity" (Max Weber), even identity of the class group, than by the explicit plan that she has prepared for this lesson. This deep-seated belief becomes, I think, extremely clear in her use of the word "we":

T: "Yacht" also has something to do with shipping, and we have done much in this area and that's why we have so many words about it.

Who - one might ask after looking at the composition of the class - is meant by "we"?

The effective functioning of the "monolingual habitus" is also clearly evident when the strategy of this teacher - who tries to elicit what is, in her opinion, the "correct" answer with an appeal to "we" - does not have the desired effect. She does not question the strategy at all. She does not see that her own assumption about the students' relationship to language presents a problem. Instead, she manages the situation by using explanations and implications that she has at hand. She seizes on the attitude of uncooperativeness of the student (which, by the way, is not too unusual in classrooms): 
T: Yes, if you would participate normally then it wouldn't be a problem, but if you don't do that. .

In my reading of this particular incident, the security and confidence which protect the teacher from being disturbed by the class's reaction stem from her "habitus". In a book entitled Der monolinguale "habitus" der multilingualen Schule (The "monolingual habitus" in the Multilingual School), I show that the assumption of a specific "monolingual habitus" by the teaching staff goes beyond the particular case and the particular situation in the German school (Gogolin, 1994 - the title has been translated from German). My empirical research shows how the "monolingual habitus" characterises the behaviour of practising German teachers today. In fact, this concept can be seen as an applied case of Bourdieu's "habitus"concept, and for research-purposes it supplies a multiplicity of points of orientation in the attempt to better understand current practices in language education - not only as far as German schools are concerned, but for European state schools in general.

\section{THE "MONOLINGUAL HABITUS" AS "TERTIUM COMPARATIONIS" IN INTERNATIONAL COMPARATIVE RESEARCH ON LANGUAGE TEACHING}

If one has a closer look at research on language teaching, it is clear that experience in teaching in the multilingual constellation has not been given much attention in Europe. Thus, what is nowadays the norm in many schools in western European countries where there has been substantial immigration remains largely unmonitored. An illustration of how immigration has affected schools in Europe, at least in urban areas, can be found in some of the data on the composition of classes collected in a comparative research project we carried out in three schools in Holland, Hamburg and London. I will refer to it briefly:

In all three schools, nearly $50 \%$ of the children had a monolingual background, coming from families which had long been settled in the respective nation state. The other half represented more than 15 nationalities with about 20 different home languages in the German case; more than five nationalities and ten home languages in the other case studies. For all the children in these schools multilingualism forms part of their daily experience. In the German case, for example, the German language plays the role of lingua franca for everybody in the school, but alongside German it has become commonplace for the children to use other languages actively: during games one child counts in Turkish, another gives greetings or thanks in Italian, others know Portuguese tongue-twisters or Polish "choosing-rhymes", and one swears fluently in many languages. The diversity of language is an important aspect for all the children in their daily language experience, be they themselves mono- or multilingual. Independent of whether or not the school pays attention to it, diversity of language is a common element of the socialisation of all children in a society which includes immigrants. Schools should, therefore, take this into account when they set teaching standards and goals.

The question of whether and how schools have up to now taken account of the diverse background of their learners in teaching in the language of the majority (e. g. German in Germany) should therefore be a central research question, at least for those schools which are situated in urban areas. However, a survey of research in the field of language teaching 
makes it clear that the problem of multilingualism as an element in the learning of language for all children in such schools has not been acknowledged. Nor, then, has multiculturalism been seen as a factor that radically calls in question common teaching practice or approaches to language teaching as a whole. The use of the concept "monolingual habitus" as a common feature in making comparisons would, I believe, provide a means of addressing this hiatus. So one line of argument in my plea for the use of "monolingual habitus" as a "tertium comparationis" in European research is based on increasing internationalisation of societies which results in linguistic and cultural diversity in the schools.

The second line of argument focuses on methodology. The further one moves away from the relatively secure terrain of organised forms of schooling, the more difficult it becomes to understand at least something of the complex process of teaching, and to gain insights from international comparisons. It is relatively easy to observe organisational aspects in schools, for example the time being given to a subject. But the more deeply one delves into the inner spheres of practical teaching processes, the more difficult the task becomes. In a lecture given in October 1992 in Hamburg, Herrlitz distinguishes three levels in international comparison:

- The first level is in the area of the field structure of the lesson, where an attempt is made to draw distinct borders between subject areas or areas of teaching within various national contexts. Several research projects on mother tongue teaching in Europe are currently underway, for example those which form part of the IMEN research-programme (International Mother Tongue Education Network).

- The second is the level of structuring interaction in the lesson. On this level patterns of interaction and activity are compared, for example repetitive patterns such as "(teacher) question - (student) answer - evaluation".

- As a third level Herrlitz has identified metonymical structures in practical classroom activities. Through this defined area, Herrlitz has addressed the parspro-toto (part for the whole) view of the interactive process in the classes. In order to explain this, he uses the picture of an iceberg: what is visible is only the smallest part of the interaction. Almost all motives, grounds and reasons for the activity remain "underwater", retreating from easy observation as well as from easy definition. To this belong numerous imponderables which by chance co-govern teaching situations. These range from the teacher's anger before breakfast to the children's not paying attention because of the comic books under their desks. But to this area belongs, also, every type of experience, previous knowledge and routine activity which all participants in the lesson, teacher and students, have access to each in their own way. The attempt to identify the moments that systematically determine aspects of the lesson is the most difficult aspect of research on teaching, be it comparative or not.

I would argue that it is on this third level, that the concept of "monolingual habitus" is particularly useful. It provides the conceptual framework that makes it possible to describe a part of what Herrlitz terms the "underwater" occurrences in the actual lesson. The "monolingual habitus" situates common-sense beliefs, basic concepts, or theoretical patterns as elements of the practical professional knowledge or the practical professional behaviour of teachers. 
The international comparison, using the concept of "monolingual habitus" as its basis, makes it possible, for example, to follow-up the question of which aspects of routine teacher activity are related to a particular national tradition in the lesson, and which aspects can be attributed to rather general elements of the professional "habitus" of teachers across cultural boundaries.

I want to give you a final example, which I think points to the potentially enriching role of the "monolingual habitus" as "tertium comparationis". Events like the one quoted below (again taken from the Hamburg-Holland-Project) took us on the track of habitual expectation. In the lesson, the teacher in the Dutch project-school assumes that all the children in her class command a common and identical feeling for language - a feeling, which is moulded in the same way as the teacher's own.

It is routine procedure for the teacher in our Dutch case study to bring an orthographic rule to light in the following way:

She says to the children: "Listen carefully; when you listen, then you'll hear how one spells."

This directive is to be understood as a paraphrase of a standard formula, which is a Dutch description of language, passed on as a "basic didactic rule" in the conventional training of Dutch teachers (Sturm, 1992).

If this formulation is used without understanding that it deals with a convention; and it is seen as an attempt to describe what actually happens during learning and therefore as an aid to the process of understanding or learning of language, its fallaciousness is not difficult to expose. Only when an individual develops his or her habits of language perception in a monolingual context, and exactly in the variant of the language in which the written text was developed, is it possible to "hear" how something should be written. And even then, you must know how to write a sound within the standard orthographic conventions before you are able to "hear" how it is written.

Thus, the directive of the teacher to "hear how you write" is meant to teach, but it can at best work with children when they have the same hearing habits as the teacher herself. Further, the directive assumes that the children already know the orthographic conventions which actually still have to be learned. All those children who have had a different experience of reception (whether they have grown up in a multilingual atmosphere or whether they have grown up in an environment marked by dialect) are left out of account by this teaching method.

The fallacy of this commonly used teaching method was readily apparent to the German research team. The researchers themselves did not "hear" in the way the Dutch teacher expected. For them, Dutch was a foreign language. Although they were sensitive to language, their feeling for the language was not what the Dutch teacher assumed. Therefore the directive which was meant to be helpful did not make any sense to the German observers. This explains too why the Dutch partners in the project failed to identify the problem in the teaching at first. Their implicit knowledge and their feeling for language, as educated Dutch native speakers, accorded with the teacher's. 
I have used this example at the end of my article to emphasise the structural similarity between the routine teaching methods in European schools. These derive from the fact that teachers unconsciously "appeal to a feeling for language". The teaching method results from teachers in the monolingual nation states being governed by their "monolingual habitus". Even at this early stage in the research project, there is sufficient evidence to persuade me that we are dealing with a basic belief which goes beyond the bounds of national tradition. This makes it essential that the research be pursued not only in Europe. Although there are fundamental differences between the situation in Europe and that in South Africa, there seem to be implications for South Africa. Research should be undertaken to identify the extent to which the "monolingual habitus" is a hindrance to learning in multilingual classes where "minorities" (in the sense that their languages are not at present accorded an equitable status) are taught through the medium of English.

\section{BIBLIOGRAPHY}

BOURDIEU, PIERRE.1979. Entwurf einer Theorie der Praxis. Frankfurt: Suhrkamp.

BOURDIEU, PIERRE. 1984. Die feinen Unterschiede: Kritik der gesellschaftlichen Urteilskraft. Frankfurt: Suhrkamp.

BOURDIEU, PIERRE.1985. Sozialer Raum und "Klassen"; Leçon sur la leçon. Zwei Vorlesungen. Frankfurt: Suhrkamp.

BOURDIEU, PIERRE. 1987. Sozialer Sinn: Kritik der theoretischen Vernunft. Frankfurt: Suhrkamp.

CLYNE, MICHAEL. 1991. Community languages: The Australian experience. Cambridge: CUP.

GOGOLIN, INGRID.1988. Erziehungsziel Zweisprachigkeit. Konturen eines sprachpädagogischen Konzepts für die multikulturelle Schule. Hamburg (Bergmann \&Helbig)

GOGOLIN, INGRID. 1992. Interkulturelles sprachliches Lernen: Überlegungen zu einer Neuorientierung der allgemeinen sprachlichen Bildung, Deutsch lernen, Heft, $2: 183-197$

GOGOLIN, INGRID. 1993. Theorien sprachlicher Sozialisation und sprachliche Pluralität. In: Deutsch lernen, Heft, 1:14-25.

GOGOLIN, INGRID. 1994. Der monolinguale "habitus" der multilingualen Schule. Münster, New York: Waxman-Verlag.

GOGOLIN, INGRID AND URSUAL NEUMAN (Eds). 1997. Großstad-Grundschule: Eine Fallstudie 
HECKMANN, FRIEDRICH. 1992. Ethnische Minderheiten, Volk und Nation. Soziologie inter-ethnischer Beziehungen. Stuttgart: Enke-Verlag.

HOBSBAWM, ERIC J. 1991. Nationen und Nationalismus: Mythos und Realität seit 1780. Frankfurt, New York: Campus.

HOHMANN, MANFRED AND HANS H REICH (Eds). 1989. : Ein Europa für ehrheiten und Minderheiten: Diskussion um interkulturelle Erziehung. Münster: Waxmann.

KROON, SJAAK.1986. Interkultureller Sprachunterricht. In: Diskussion Deutsch, Heft 90: $413-423$

KROON, SJAAK AND TON VALLEN. 1991. Monolinguale Lehrer in multilingualen Klassen. In: Gogolin, I, M Krüger-Potratz, S Kroon, U Neumann \& T Vallen (Eds). Kultur- und Sprachenvielfalt in Europa. Münster: Waxmann:125 - 149.

KROON, SJAAK AND JAN STURM. 1994. Das nationale Selbstverständnis im Unterricht der Nationalsprache: Der Fall der Niederlande. In: Gogolin, 1. (Ed.). Das nationale Selbstverständnis der Bildung. Münster: Waxmann:151 - 182.

LIEBAU, ECKART AND LUDWIG HUBER. 1985. Die Kulturen der Fächer. In: Liebau, E and S Müller-Rolli (Eds). Lebensstil und Lernform, Heft 3 der Neuen Sammlung:314 - 339. 